MATEC Web of Conferences 22,04006 (2015)

DOI: $10.1051 /$ matecconf/ 20152204006

(C) Owned by the authors, published by EDP Sciences, 2015

\title{
Settlement Impact Analysis and Countermeasure Research of the Down Traversing Formed by the Double-Arch Subway Tunnels through the Existing Railways in Loess Area
}

\author{
Lixin Wang* \\ Chang'an University, Xi'an, Shaanxi, China \\ China Railway First Survey and Design Institute Group Co., LTD, Xi'an, Shanxi, China
}

\begin{abstract}
With the large-scale construction of city subways, the down traversing formed by subway running tunnels through the existing railways or railway yards are increasing day by day. Down traversing in shield method becomes common; however, the engineering cases which can be referable in the down traversing formed by the shallow-buried excavation of double-arch tunnels through the existing railways are very little. The ability to effectively control the excavation of shallow-buried subway tunnels can directly affect the safety of railway operation. According to the engineering characteristics of the down traversing formed by the shallow-buried excavation of double-arch tunnels in loessial layer, this paper proposed the standards for railway bed and track settlement control, and offers underground water treatment measures with assistant steps implemented on the ground surface during construction, so as to ensure the railway operation safety during the construction of the tunnel. Moreover, this paper applied MIDAS-GTS finite element software to make numerical simulation analysis of the down traversing formed by the double-arch tunnel through the railway and obtained the deformation laws during down traversing. The calculations suggest the railway track deformation caused by the down traversing construction of the double-arch tunnel in this project can meet related control standard requirements. There's certain reference value contained in the deformation laws for the point locations of monitoring measurement. The research conclusions can provide scientific proof and technical guidance for the design and construction of this running tunnel project in order to offer reference for similar projects in the future.
\end{abstract}

Keywords:subway, double-arch tunnel, existing railway, settlement control, groundwater control, deformation laws

\section{INTRODUCTION}

According to statistics and in combination with the engineering cases of the down traversing formed by domestic subway tunnels through the existing subways or railway yards, down traversing in shield method becomes common. However, the engineering cases which can be referable in the down traversing formed by the shallow-buried excavation of double-arch tunnels through the existing railways are very little. No similar engineering experience can be referred to in the down traversing formed by the shallow-buried excavation of double-arch tunnels through the existing railways in loess area.

As is well known, the requirements for the settlement control of railway beds and tracks are very strict in railway operation. Tunnel precipitation and excavation are the redistribution of formation stress. And thus, tunnel construction will definitely generate certain disturbance to the surrounding stratums and lead to the redistribution of the soil mass stress around tunnels which may cause stratum displacement and ground settlement of various degrees or even affect the normal operation of railways. In order to ensure the safety of tunnel construction and railway operation, it is very necessary to study the impact that the excavation construction of shallow-buried tunnels has through the existing railways in loess area. This paper took the down traversing formed by the double-arch tunnel of Xi' an No.5 Metro Line on Xikang Railway as the case for study. In accordance with the engineering characteristics of the down traversing formed by the shallow-buried excavation of double-arch tunnels through the existing railways in loess area, this paper studied the control standards for the railway settlement caused by the down traversing of the double-arch tunnel, the deformation laws of stratums and tracks, underground water treatment measures and assistant measures for surface construction. The research conclusions can provide scientific proof and technical guidance for the design and construction of this running tunnel project in order to offer reference for similar projects in the future.

\section{PROJECT PROFILE}

The first-stage project of Xi'an No.5 Metro Line, from Fangzhi City Railway Station to the terminal point of the first stage, is of underground layout. Out from the

*Corresponding author: $\underline{458601714 @ \text { qq.com }}$

This is an Open Access article distributed under the terms of the Creative Commons Attribution License 4.0, which permits unrestricted use, distribution, and reproduction in any medium, provided the original work is properly cited. 


\section{MATEC Web of Conferences}

Fangzhi City Railway Station, the metro line down traverses Xikang Railway until it reaches the terminal point of the path. The overallength of this section is $243 \mathrm{~m}$. The shallow-buried subsurface excavation method is planned to be applied. The down-traversing part on Xikang Railway will be in double-arch tunnel frame. The excavation width of the tunnel will be $11.6 \mathrm{~m}$ with an excavation height of $6.8 \mathrm{~m}$. The apex of tunnel arch is about $20 \mathrm{~m}$ away from Xikang Railway. The stratums traversed by the running tunnel are mainly composed of 4-2 ancient soil, 4-3-1 silty clay, 4-11-1 pebble bed and 4-6-1 fine silt layer. During the reconnaissance period, the underground water level is below ground for $16.40 \mathrm{~m}$.

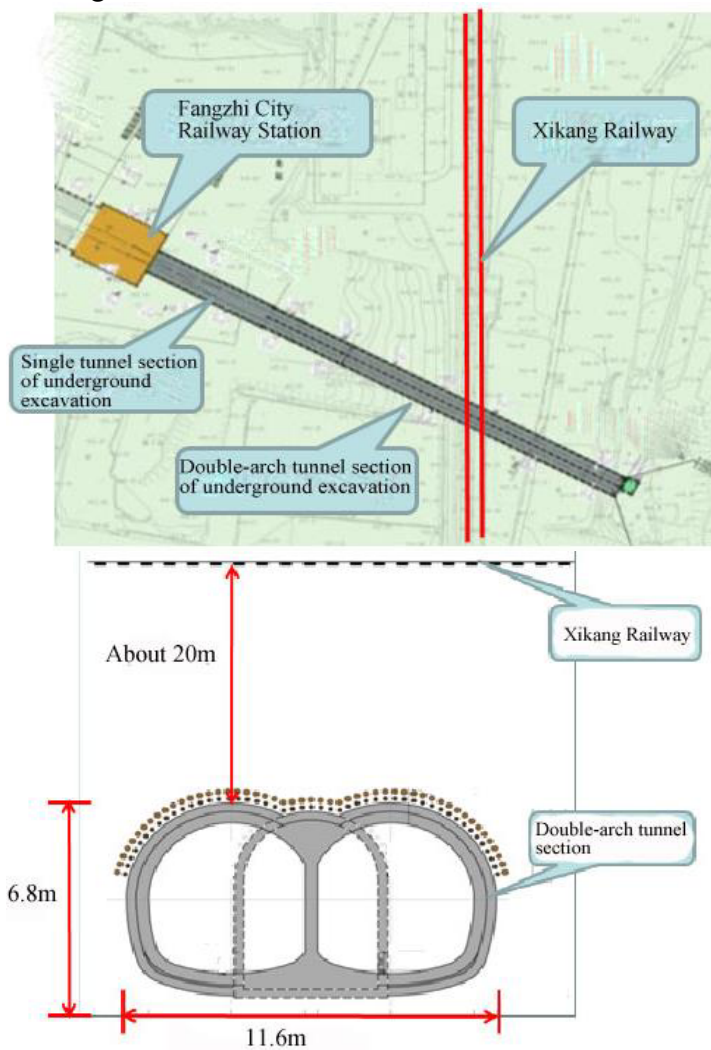

Figure 1.Relation graph of the cross and vertical sections of the tunnel and xikang railway

Belonging to the constituent part from Baotou to Liuzhou of the "Eight Verticals and Eight Horizontals" Highway Networking Planning of he Ministry of Railways, Xikang Railway is a new passage to enter Chongqing center and Sichuan Province from North China and Northwest territories. Xikang Railway construction was commenced on December $18^{\text {th }}, 1996$ and was completed in October, 2001 with an overall length of $268 \mathrm{~km}$ and a designed speed of $160 \mathrm{~km} / \mathrm{h}$. Xikang Railway is made of reinforced concrete sleepers and ballast beds, connecting the southwestern part of China.

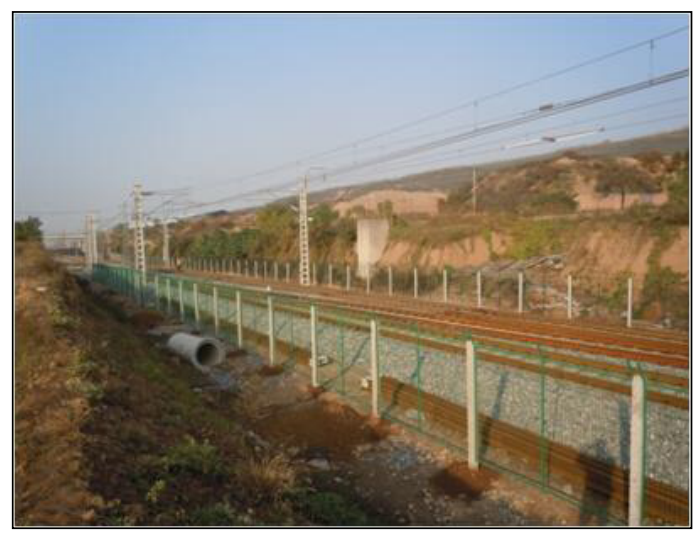

Figure 2. Status Map of Xikang Railway

\section{RESEARCH OF THE STANDARDS FOR RAILROAD BED AND TRACK SETTLEMENT CONTROL}

As the surface subsidence caused by the construction of shallow-buried tunnel may lead to major deformation in the railway track and thus leave an influence on the normal operation of the railway, the maximum permitting deformation of the railway track must be determined. During the construction of the shallow-buried tunnel, the deformation limits of the railway track must be strictly controlled; the allowable deviation management numerical values set for the static-state geometric dimensions of sleeper, steel rail and track in the Rail Track Repair Regulations must be strictly conformed to; and relative requirements for the allowable deviation management numerical values set for the dynamic condition of track must be strictly satisfied. See Table 1 given below for the static-state geometric dimensions of sleeper, steel rail and track.

According to the practical experience, control standards and relevant specifications obtained in the cases of the down traversing formed by the subways through railways in Beijing, Guangzhou and Shanghai, and in combination with the underground tunnel excavation construction experience accumulated in $\mathrm{Xi}$ 'an and the engineering geological conditions of this subway running tunnel, the following control standard values should be applied in the down traversing part of the underground excavation tunnel construction from Fangzhi City Railway Station to the terminal point of the first stage of Xi'an No.5 Metro Line through Xikang Railway (specific standard values need to be confirmed through communication with related railway ownership departments):

(1)The maximum deformation values of railroad bed and ground shall be within $+2 \sim-10 \mathrm{~mm}$;

(2)The maximum settlement value or upheaval value of rail surface shall be less than $8 \mathrm{~mm}$;

(3) The twist of track of two adjacent steel rails shall not exceed $6 \mathrm{~mm}$;

(4) The maximum differential settlement value be- 
ICETA 2015

Table 1. The allowable deviation management numerical values set for the static-state geometric dimensions of railway track

\begin{tabular}{|c|c|c|c|c|c|c|c|c|c|c|c|c|c|}
\hline \multirow{2}{*}{\multicolumn{2}{|c|}{ Project }} & \multicolumn{3}{|c|}{$v_{\max }>160 \mathrm{~km} / \mathrm{h}$ Main track } & \multicolumn{3}{|c|}{$\begin{array}{l}160 \mathrm{~km} / \mathrm{h} \geq v_{\max } \\
120 \mathrm{~km} / \mathrm{h} \text { Main track }\end{array}$} & \multicolumn{3}{|c|}{$\begin{array}{l}v_{\max } \leq 120 \mathrm{~km} / \mathrm{h} \\
\text { Main track and arri- } \\
\text { val-departure track }\end{array}$} & \multicolumn{3}{|c|}{ Other station tracks } \\
\hline & & $\begin{array}{l}\text { Acceptance } \\
\text { of Works }\end{array}$ & \begin{tabular}{|l|} 
Fre- \\
quent \\
Mainte \\
nance \\
\end{tabular} & $\begin{array}{l}\text { Urgent } \\
\text { Repair }\end{array}$ & \begin{tabular}{|l} 
Ac- \\
ceptanc \\
e of \\
Works
\end{tabular} & $\begin{array}{l}\text { Fre- } \\
\text { quent } \\
\text { Mainte } \\
\text { nance } \\
\end{array}$ & $\begin{array}{l}\text { Urgent } \\
\text { Repair }\end{array}$ & \begin{tabular}{|l|} 
Ac- \\
ceptanc \\
e r of \\
Works
\end{tabular} & $\begin{array}{l}\text { Fre- } \\
\text { quent } \\
\text { Mainte } \\
\text { nance } \\
\end{array}$ & $\begin{array}{l}\text { Urgent } \\
\text { Repair }\end{array}$ & $\begin{array}{l}\text { Ac- } \\
\text { ceptan } \\
\text { ce of } \\
\text { Works }\end{array}$ & $\begin{array}{l}\text { Fre- } \\
\text { quent } \\
\text { Maint } \\
\text { enance }\end{array}$ & $\begin{array}{l}\text { Urgent } \\
\text { Repair }\end{array}$ \\
\hline \multicolumn{2}{|c|}{ Track Gauge(mm) } & $+2-2$ & $+4-2$ & $+6-4$ & $+4-2$ & $+6-4$ & $+8-4$ & $+6-2$ & $+7-4$ & $+9-4$ & $+6-2$ & $+9-4$ & $+10-4$ \\
\hline \multicolumn{2}{|l|}{ Level(mm) } & 3 & 5 & 8 & 4 & 6 & 8 & 4 & 6 & 10 & 5 & 8 & 11 \\
\hline \multicolumn{2}{|l|}{ Height $(\mathrm{mm})$} & 3 & 5 & 8 & 4 & 6 & 8 & 4 & 6 & 10 & 5 & 8 & 11 \\
\hline \multicolumn{2}{|c|}{$\begin{array}{l}\text { Track Direction (straight } \\
\text { line })(\mathrm{mm})\end{array}$} & 3 & 4 & 7 & 4 & 6 & 8 & 4 & 6 & 10 & 5 & 8 & 11 \\
\hline \multirow{2}{*}{$\begin{array}{l}\text { Twist } \\
\text { Track(twist)( } \\
\text { mm) }\end{array}$} & $\begin{array}{l}\text { Easement } \\
\text { Curve }\end{array}$ & 3 & 4 & 6 & 4 & 5 & 6 & 4 & 5 & 7 & 5 & 7 & 8 \\
\hline & $\mid \begin{array}{lr}\text { Straight } & \text { Line } \\
\text { and } & \text { Circular } 3 \\
\text { Curve } & \end{array}$ & & 4 & 6 & 4 & 6 & 8 & 4 & 6 & 9 & 5 & 8 & 10 \\
\hline
\end{tabular}

tween two tracks shall be less than $6 \mathrm{~mm}$;

(5) The differential settlement value within $10 \mathrm{~m}$ of a single track shall be less than $8 \mathrm{~mm}$;

(6) The change value of track gauge shall be within $-4 \sim+8 \mathrm{~mm}$.

Note: this standard is the control standard when there's no speed limit set for the trains running in this tunnel construction area and the railway can allow urgent repair. The control standard is a comparatively strict one.

\section{NUMERICAL SIMULATION ANALYSIS}

In order to verify the feasibility of the design plan and the engineering project, and to ensure the operation safety of the existing railway during the down traversing of the tunnel, this paper established a three-dimensional finite element model for this project and obtained the deformation laws of the railway track during the down traversing period of the tunnel with the key control steps of double-arch tunnel excavation. Besides, it also proposes suggestions for the layout of monitoring measurement points.

\subsection{Calculation Model}

The simulation applied large general finite element program MIDAS/GTS to establish models for computational analysis. The group division was made in accordance with different structures, excavation districts and excavation boundaries. The simulation of the construction phase was processed through the three-dimensional strain modeling and the center drift method was applied. There were 13 construction steps. See Figure 3 and Figure 4 for the excavation sequence map and the three-dimensional computational model. The boundary conditions of the model are as follows: set the bottom fixation direction as $\mathrm{Z}$ direction; set the left and right boundary interface fixation direction of the tunnel cross section as X direction; set the longitudinal fixation direction of the front and back tunnel boundary interfaces as Y direction; and set the top surface as the free surface. In order to eliminate the influence left by the boundary conditions, take the crosswise area of this computational domain as $70 \mathrm{~m}$ and the vertical area as $50 \mathrm{~m}$. Take a distance of $30 \mathrm{~m}$ from each side of the tunnel which is almost equal to 3 times of the tunnel excavation span. Take a distance of $22 \mathrm{~m}$ from below the tunnel floor which is almost equal to 3 times of the tunnel excavation height. Take a distance of $50 \mathrm{~m}$ along the vertical direction of the tunnel. The intersection angle of railway track central line and the tunnel central line is about $62^{\circ}$. The effect of the big pipe shed and the advanced small pipe grouting shall be realized by improving soil mechanical parameters without considering the impact that the pore-forming process of the pipe shed and the small pipe may have on the surrounding rocks. Use M-C (Mole-Coulomb) model to simulate the reinforcement materials for soil layers and grouting. Elastic model simulation is used for elementary support and temporary support; beam element model simulation is used for railway track; shell element model simulation is used for elementary support and temporary support; and entity unit simulation is used for other materials. See Table 2 for the physical and mechanics parameters of each soil layer at the site.

\subsection{Tunnel working methods and support parameters}

Double-arch facture surface method is applied in the underground tunnel excavation; whereas the center drift method and the benching tunneling method are applied as the construction methods. According to the calculations and the experience accumulated in the 


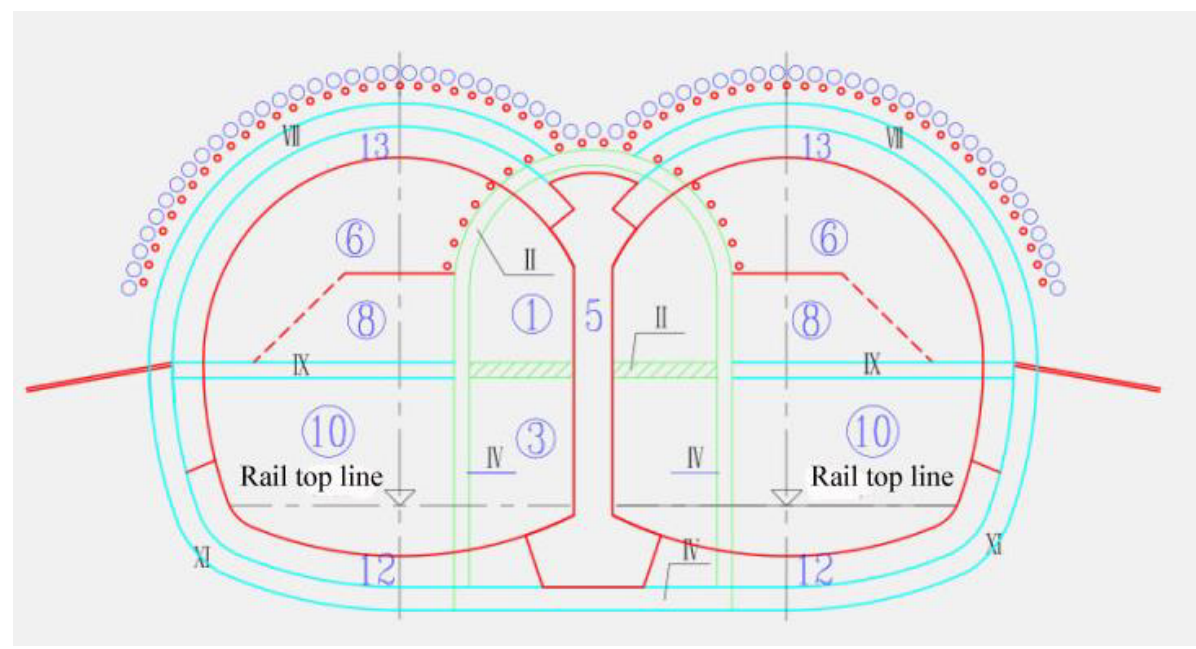

Figure 3. Excavationsequence map of center drift method

Table 2.Suggestive values of the physical and mechanics parameters of the soil layers at the site

\begin{tabular}{|l|l|l|l|l|l|l}
\hline Soil layer & $\begin{array}{l}\text { Density } \\
\mathrm{kg} / \mathrm{m}\end{array}$ & $\begin{array}{l}\text { Compression } \\
\text { modulus/Mpa }\end{array}$ & $\begin{array}{l}\text { Horizontal pressure } \\
\text { coefficient } / \mathrm{K}_{0}\end{array}$ & Poisson's ratio & $\begin{array}{l}\text { Cohesive } \\
\text { force } / \mathrm{Kpa}\end{array}$ & $\begin{array}{l}\text { Internal friction } \\
\text { angle }^{\circ}\end{array}$ \\
\hline Miscellaneous fill & 1700 & 8 & 0.43 & 0.30 & 5 & 10 \\
\hline Ancient soil & 1700 & 10 & 0.43 & 0.30 & 33 & 25 \\
\hline Old loess & 1710 & 8 & 0.4 & 0.28 & 35 & 25 \\
\hline Ancient soil & 1840 & 10 & 0.39 & 0.28 & 34 & 25 \\
\hline Silty clay & 1860 & 12 & 0.39 & 0.28 & 36 & 26 \\
\hline silty-fine sand & 2000 & 30 & 0.49 & 0.33 & 0 & 30 \\
\hline $\begin{array}{l}\text { Elementary sup- } \\
\text { port and temporary } \\
\text { support }\end{array}$ & 2300 & $\begin{array}{l}28000(\text { elastic } \\
\text { modulus) }\end{array}$ & & & & \\
\hline Mid-wall & 2500 & $\begin{array}{l}325000(\text { elastic } \\
\text { modulus) }\end{array}$ & & 0.2 & & \\
\hline
\end{tabular}

shallow-buried subway underground tunnel excavation construction in $\mathrm{Xi}^{\prime}$ an, the prepared support parameters are as follows:

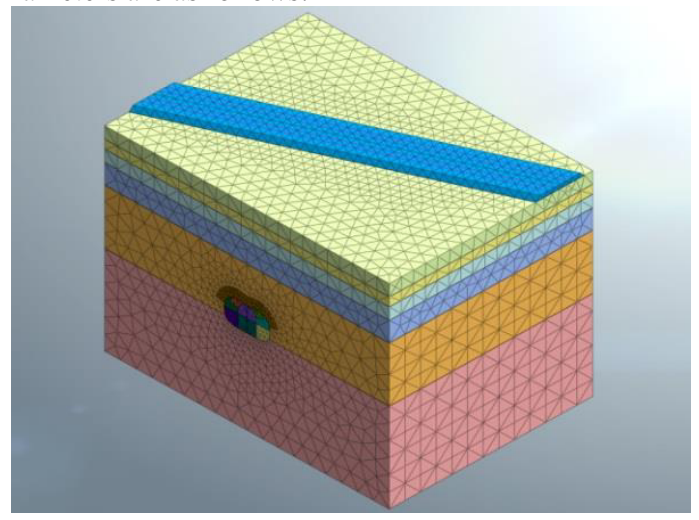

Figure 4.Three-dimensional computational model
(1)Advance support: $\Phi 108$ conventional steel pipe with wall thickness of $6 \mathrm{~mm}$. The pipes shall be placed within the range forming angles of $150^{\circ}$ around the arch part. The interval in circular direction shall be $0.40 \mathrm{~m}$ whereas the external angle shall be about $5^{\circ}$. Cement mortar shall be used as the grout. After traversing Xikang Railway, each side of the supports shall be considered to add $5 \mathrm{~m}$ in length.

(2)Advance support: $\Phi 42$ conventional steel pipe with wall thickness of $3.5 \mathrm{~mm}$ and length of $3 \mathrm{~m}$. The pipes shall be placed within the range forming angles of $150^{\circ}$ around the arch part. The interval in circular direction shall be $0.40 \mathrm{~m}$ while the external angle shall be about $10^{\circ}$. The interval in vertical direction shall be $1.5 \mathrm{~m}$. Cement mortar shall be used as the grout.

(3)Pneumatically placed concrete: $\mathrm{C} 25$ early strength concrete with thickness of $300 \mathrm{~mm}$ and full-face supporting.

(4)Grid steel frame: the intervals shall be kept as $0.5 \mathrm{~m}$. 


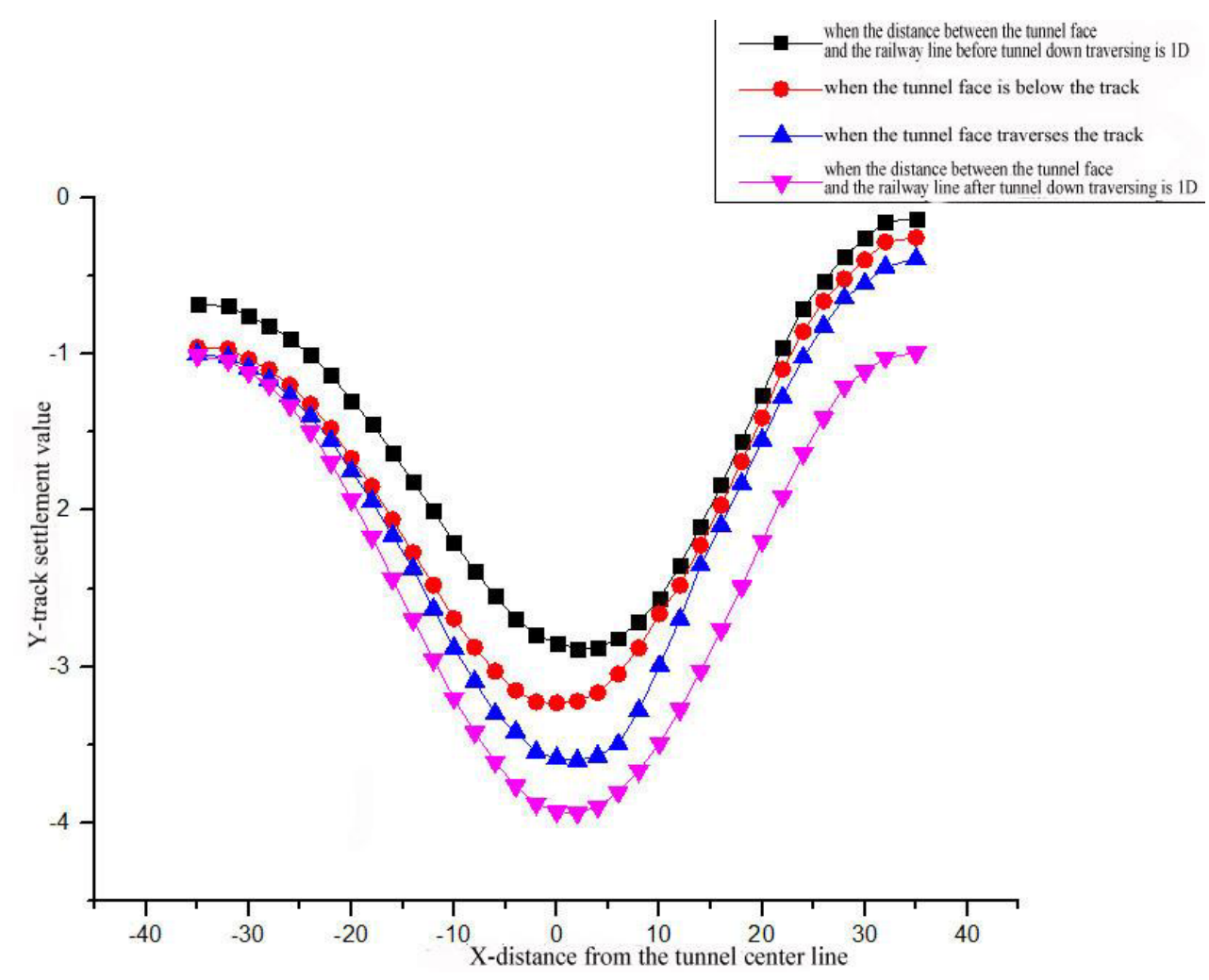

Figure 5. Settlement curves of the track during the process of the down traversing formed by the tunnel on the railway line

(5)Reinforcing mesh: A double-layer reinforcing mesh shall be placed in the full face. The steel bars placed in the circular-longitudinal direction shall all be $\Phi 8$ steel bars. A $40 \mathrm{~mm}$-thick layer of concrete shall be pneumatically placed at first. Put up the reinforcing mesh. The off-contact distance of the mesh shall be $150 \mathrm{~mm} * 150 \mathrm{~mm}$. The thickness of the pneumatically placed concrete cover for the reinforcing mesh shall be at least $20 \mathrm{~mm}$.

(6)Secondary lining: C40 waterproof reinforced concrete with impervious grade no less than P10 and thickness of $400 \mathrm{~mm}$.

(7)During the construction, 2 locking anchor pipes shall be placed at the arch foot of each side (including temporary inverted arches). $\Phi 42 \mathrm{~mm}$ steel pipes with length of $4 \mathrm{~m}$ shall be applied as the locking anchor pipes.

\subsection{Basic Assumption}

Because of the randomness and complexity contained in the physical and mechanical properties of geotechnical materials, it is very hard to completely simulate the mechanical properties of them during the modeling and calculation process, principal factors shall be considered while secondary causes shall be ignored. According to the concrete issues, this paper simplified the process to a certain degree and the following as- sumptions were applied in this numerical simulation:

(1)The surrounding rock materials are all continuous isotropous media of homogeneity.

(2)The results of calculating the tunnel stress and deformation as plan strain problems are generally safe.

(3)Only the impact of gravity stress is considered in the simulation of initial stress field. No tectonic stress is taken into consideration.

(4)Consider the impact of stress release coefficient in the tunnel excavation process. In the current excavation construction phase, the stress release coefficient of the surrounding rock is $40 \%$ and that of the next two construction phases will be $30 \%$ for each.

\subsection{Analysis of Computing Results}

According to the computing results of the numerical simulation, analysis of the down traversing formed by the tunnel on Xikang Railway has been conducted from three aspects and corresponding conclusions have been reached, so as to provide certain guidance for the tunnel construction.

1)The sedimentation value of the railway track in the situation when the tunnel face and the rail track have different distances.

According to numerical simulation, the settlement curvesof the track along the railway line when the distance between the tunnel face and the railway line 


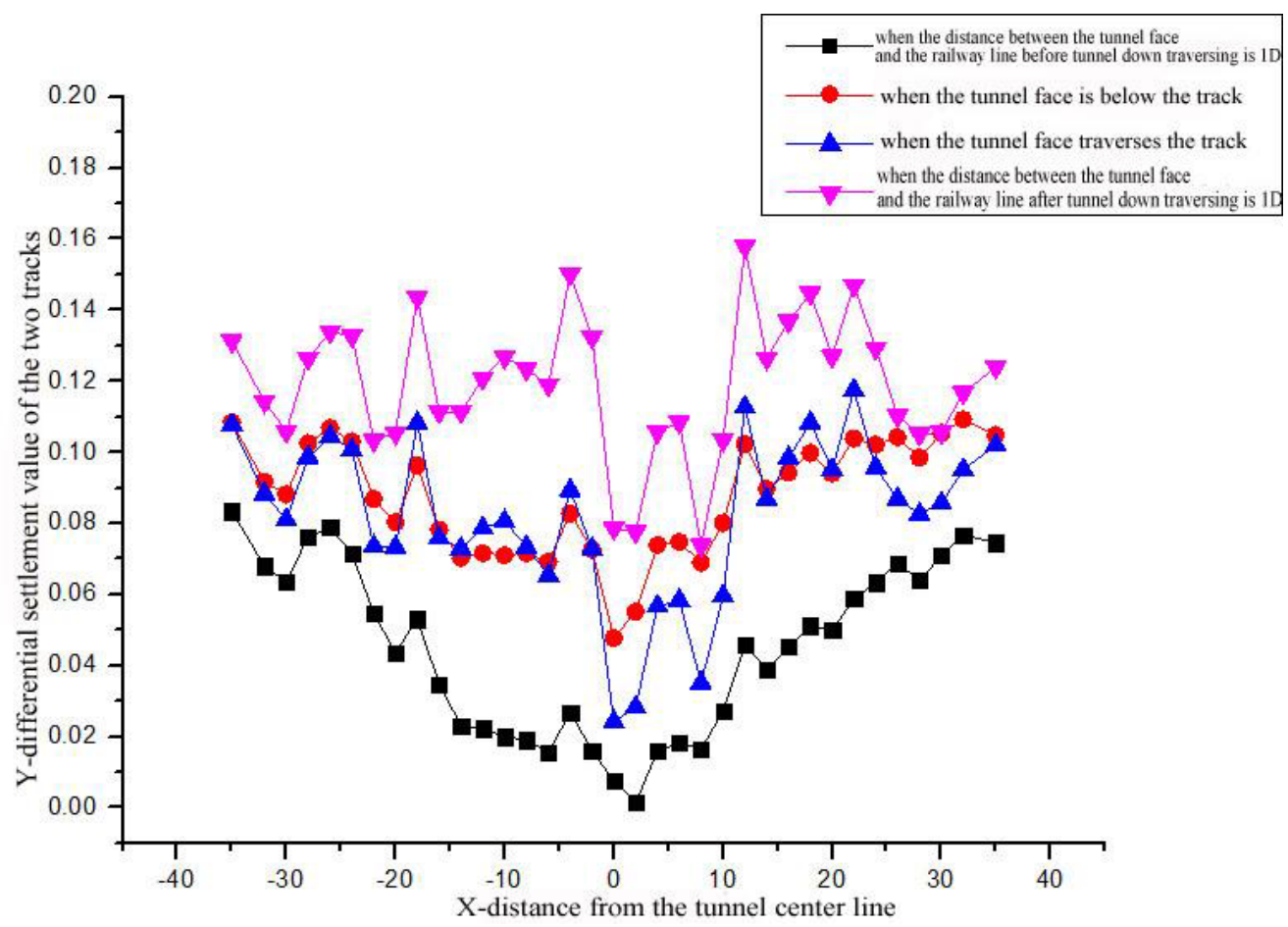

Figure 6.Differential settlement curves of the two tracks during the down traversing formed by the tunnel on the railwayline

before tunnel down traversing is 1D (D refers to the tunnel excavation span); when the tunnel face is below the track; when the tunnel face traverses the track; and when the distance between the tunnel face and the railway line after tunnel down traversing is $1 \mathrm{D}$ are respectively shown in the figure 5 .

According to Figure 5, during the process of the down traversing formed by the tunnel on the railway, the overall vertical settlement of the track structure can be controlled less than $-3.938 \mathrm{~mm}$ after reinforcing the stratum and thus can satisfy the requirements of the track structure settlement control standards. Besides, the average settlement value of the track structure within a distance of $\pm 20 \mathrm{~m}$ from the tunnel center line is bigger than $2 \mathrm{~mm}$ along the vertical direction of the tunnel. In the meantime, the distance between the maximum curvature points of tunnel excavation and the tunnel center line $\sqrt{3} \mathrm{i}$ is calculated to be about $20 \mathrm{~m}$ according to peck formula. The area between the maximum curvature points of the settling tank is the main location of soil mass settlement when the tunnel down traversing occurs. While arranging the layout of the measuring points for tunnel monitoring and reinforcing the track structure, this area shall be paid the most attention to.

2) The differential settlement value of the two tracks in the situation when the tunnel face and the rail track have different distances.

According to numerical simulation, the differential settlement curves of the two tracks in the cross section of the railway line when the distance between the tunnel face and the railway line before tunnel down traversing is 1D (D refers to the tunnel excavation span); when the tunnel face is below the track; when the tunnel face traverses the track; and when the distance between the tunnel face and the railway line after tunnel down traversing is 1D are respectively shown in the figure 6.

According to Figure 6, it can be seen that during the down traversing formed by the tunnel on the railway, the differential settlement values of the two tracks are less than $6 \mathrm{~mm}$ and thus can satisfy the requirement. The differential settlement presents a trend of being less in the middle and being more on the sides. The differential settlement values can be controlled less than $0.16 \mathrm{~mm}$. With the extension of the tunnel face, the differential settlement value between the two tracks becomes bigger and reaches its maximum value after the down traversing part of the tunnel passes through the railway.

3)The change values of the track gauge in the situation when the tunnel face and the rail track have different distances.

According to numerical simulation, the change value curves of the track gauge between the two tracks in the cross section of the railway line when the distance between the tunnel face and the railway line before tunnel down traversing is 1D (D refers to the tunnel excavation span); when the tunnel face is below the track; when the tunnel face traverses the track; and 


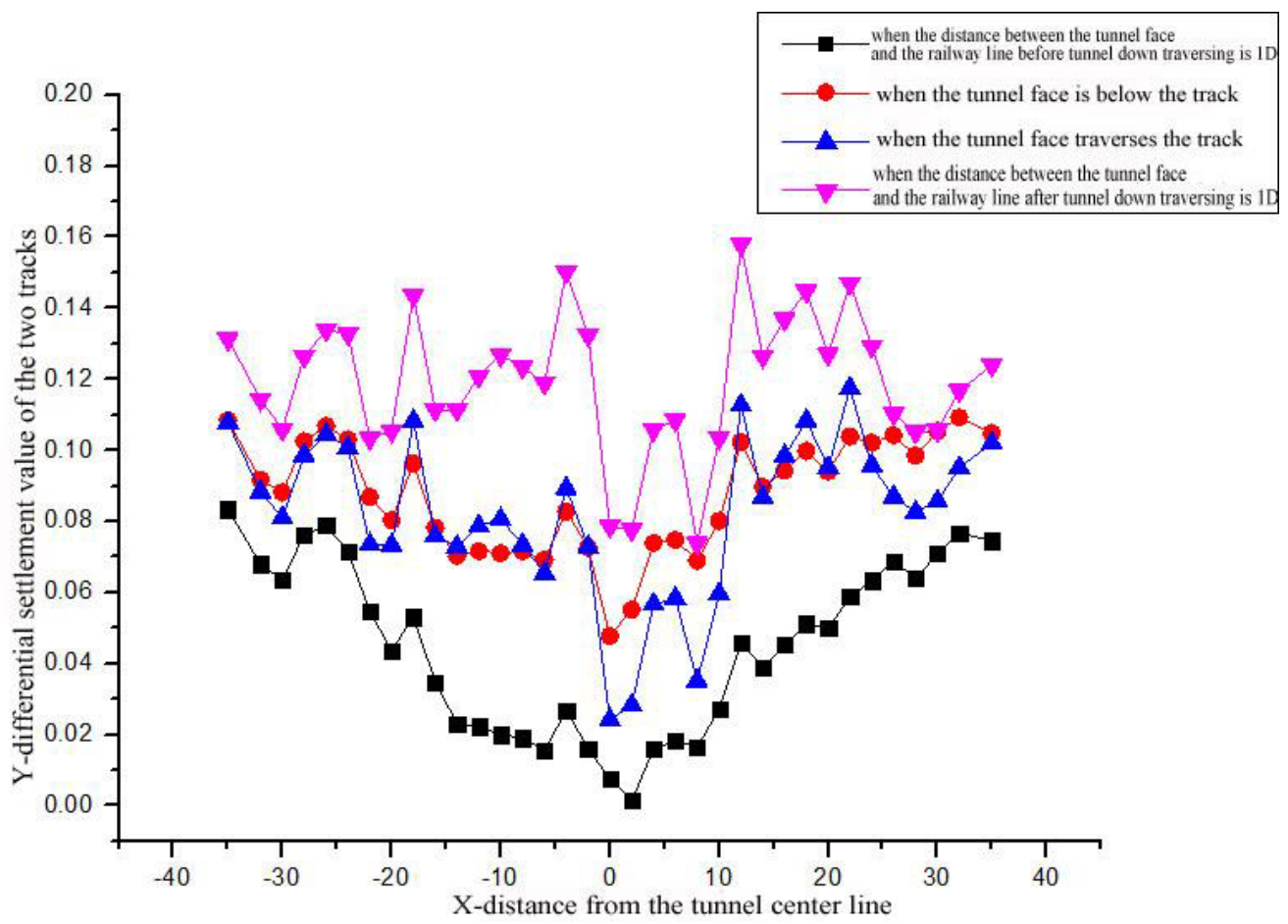

Figure 6. Differential settlement curves of the two tracks during the down traversing formed by the tunnel on the railwayline

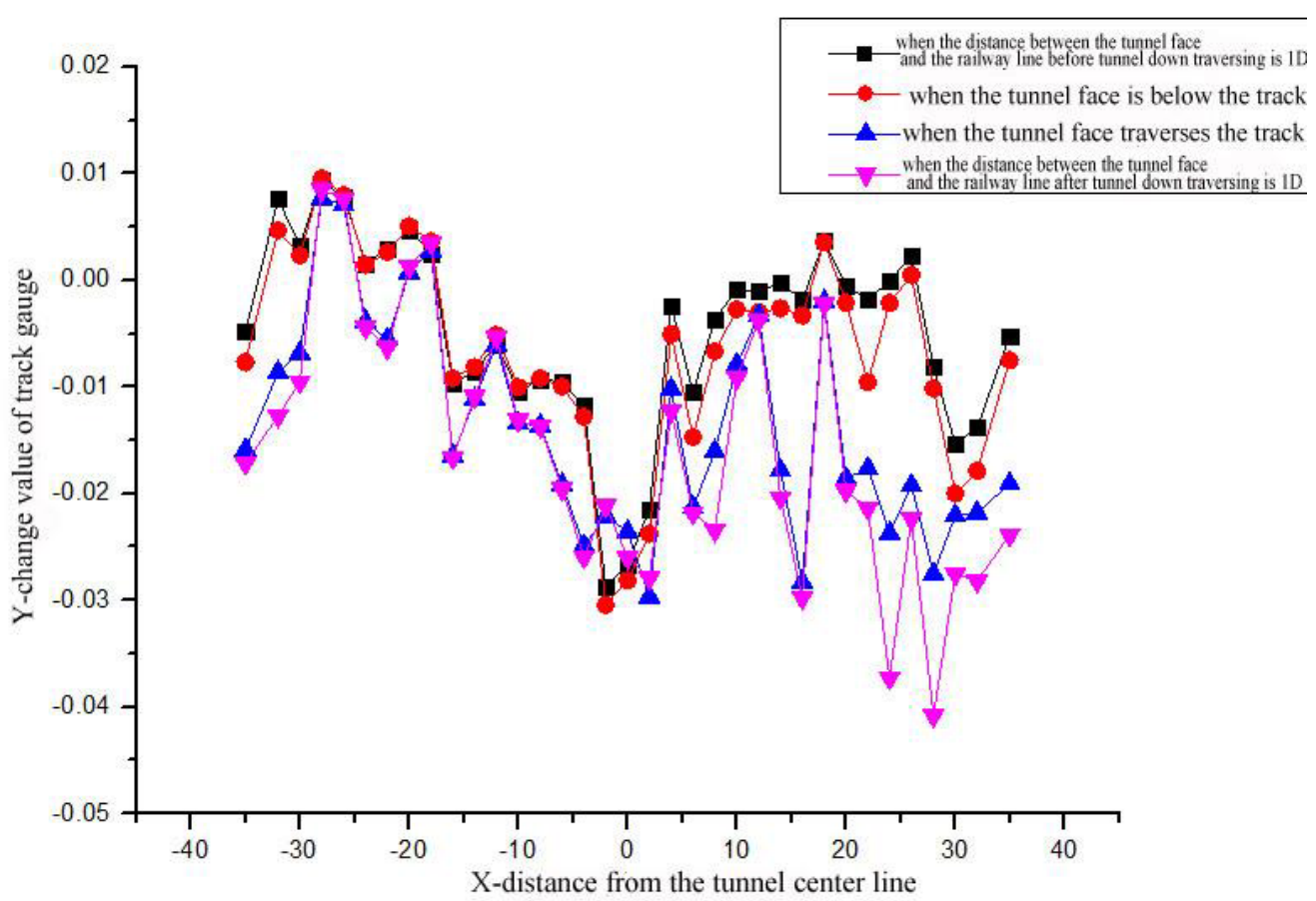

Figure 7.Change value curves of track gauge during the down traversing formed by the tunnel on the railwayline 


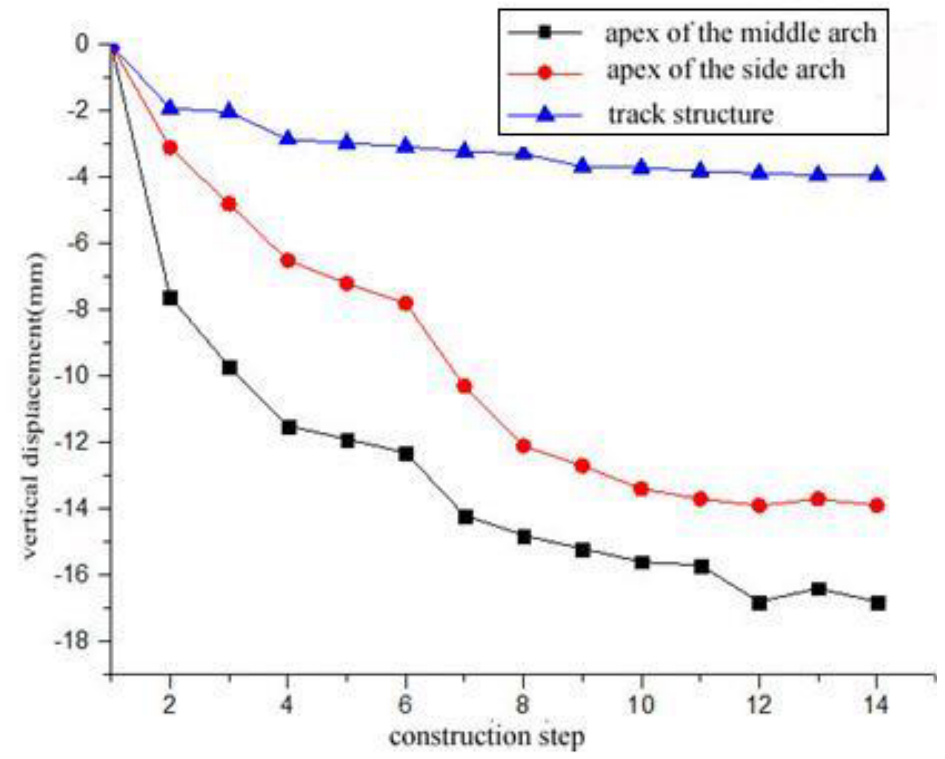

Figure8.Vertical displacement curves of tunnel and the railway line

when the distance between the tunnel face and the railway line after tunnel down traversing is 1D are respectively shown in the figure 7 .

According to Figure 7, it can be seen that during the down traversing formed by the tunnel on the railway, the change values of track gauge can be controlled within a range from $-0.05 \mathrm{~mm}$ to $+0.01 \mathrm{~mm}$ which can meet the control standard stating that the change values of track gauge shall be within a range from $-4 \mathrm{~mm}$ to $+8 \mathrm{~mm}$. With the extension of the tunnel face, the overall trend of the track gauge change value is becoming bigger and it will reach its maximum value after the down traversing part of the tunnel passes through the railway.

4)Curve of Railway Track Settlement Process during the Down Traversing of the Tunnel:

According to the calculating results shown in Figure 8 , during the construction of the tunnel, settlement deformation of different degrees occurred in the surrounding rock and the railroad beds. The settlement deformation value of the tunnel arch apex was the maximum one while that of the ground surface was the minimum one. The maximum value of arch apex settlement during the tunnel construction was $16.8 \mathrm{~mm}$ and the maximum settlement value of the railroad beds was $3.94 \mathrm{~mm}$,both of which met the requirements of the control standards.

With the progress in the excavation and supporting of the running tunnel, the settlement deformation on the railroad beds increased. The settlement value of the railroad beds caused by the excavation of the upper part of the middle hole reached $9.7 \mathrm{~mm}$. This value reached $11.9 \mathrm{~mm}$ after the construction of the middle hole was completed, accounting for $70 \%$ of the overall deformation value. The control of the impact that the excavation of the middle hole has on the railroad beds shall be regarded as the key part in construction.

The numerical calculating results suggest that during the down traversing formed by the tunnel on Xikang Railway after the soil mass was reinforced, the indexes of rail track settlement value, differential settlement value and track gauge change value could meet the corresponding control values required in the deformation control standards. These results can show that the design plans of the construction methods, excavation working procedures and support parameters of this project are all reasonable and feasible.

\section{ASSISTANT MEASURES FOR THE CON- STRUCTION}

\subsection{Underground Water Treatment Measures}

Numerical simulation was conducted when precipitation was not considered. As the impact of the precipitation in the underground excavation construction on the yard surface settlement is great, how to take proper underground water treatment measures to reduce stratum settlement as much as possible is the key to ensuring the smooth construction of this project. According to the statistics of the underground tunnel excavation precipitation in the stratum of this area, the ground settlement caused by precipitation is generally around $10 \mathrm{~mm}$. Therefore, no dewatering measure shall be taken. Full-sectional grouting and water plugging method shall be used for the excavation of each section, so as to ensure the anhydrous working condition 


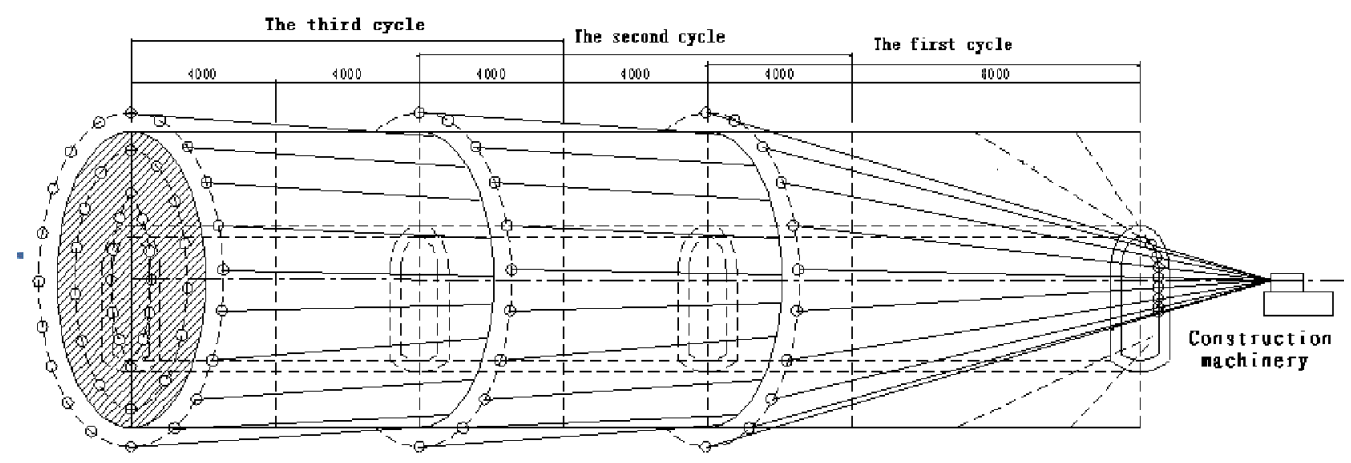

Figure 9. Schematic diagram of full-sectional grouting

of the underground excavation construction. Meanwhile, the stratum shall be reinforced in order to reduce the ground settlement and railway track deformation caused by the tunnel excavation.

Grouting reinforcement and water plugging shall be applied in the underground excavation section while deep-hole grouting shall be used for the full face. The grouting length shall be $12.0 \mathrm{~m}$ in one cycle. The layout of grouting shall be placed along the excavation contour line with an interval of $500 \mathrm{~mm}$ among the most outward three rows. The external angles shall be set as $14^{\circ}, 12^{\circ}$ and $9^{\circ}$. The splicing length of the soil mass shall be $2 \mathrm{~m}$ and the soil mass shall be placed within $2 \mathrm{~m}$ outside the reinforcement excavation line. The diffusion radius shall be $0.4 \mathrm{~m}$ and the grouting pressure shall be controlled within $0.15 \sim 0.3 \mathrm{MPa}$. Cement-water-glass grouting shall be applied for grouting. The grouting order shall be outside with interval grouting in the construction. A grouting experiment shall be conducted and the grouting parameters shall be determined before grouting, so as to ensure the reinforcement effect.

\subsection{Ground Assistant Measures}

In order to ensure the operation safety of the existing railway, the specific plans given below have been arranged for the special project of the existing tracks:

a. Precautionary Measures

Before the construction of down traversing, the following precautionary measures shall be taken for the route within the protective design range:

(1) Conduct complete inspection on the steel rails, fasteners and track beds. The adjusted tracks shall meet the requirements set in the "Acceptance of Works" corresponding to Chapter 6 of Rules of Rail Track Repair. The implementation of the measures shall be guaranteed and the rail tracks shall be in stable state. Record the temperature of the continuously welded rail tracks and the situation of longitudinal displacement.

(2) Longitudinal and horizontal rail beams and protective measures for hanger rails shall be placed on each rail line of the railway that locates in the middle part of the settling tank as shown in Figure 10.

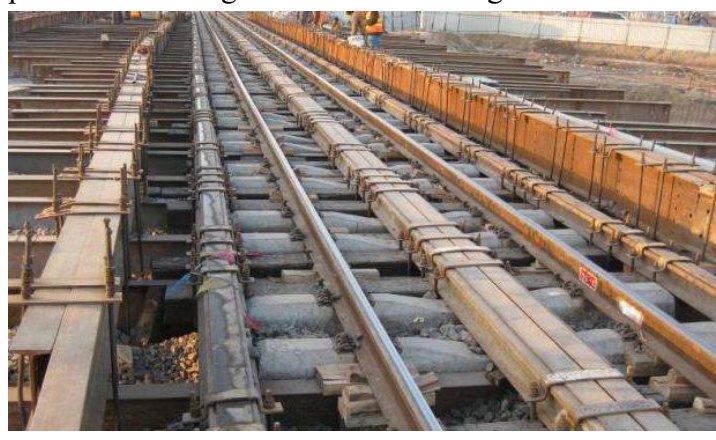

Figure 10. Status map of the track-locking reinforcement

(3) Rate-limiting operation shall be started at the beginning of the track-locking work. The suggested rate limit is $45 \mathrm{~km} / \mathrm{h}$.

(4) Formulate strict monitoring scheme to monitor the status of the railway.

(5) The railway engineering department shall reinforce the maintenance of influenced part of the national railway line. Professional railway staff shall be arranged to periodically inspect the geometrical state of the railway track gauge, direction, leveling and discretion. Corresponding measures shall be immediately taken if any abnormal situation occurs.

\section{CONCLUSION}

This paper took first-stage project of Xi'an No.5 Metro Line which is from Fangzhi City Railway Station to the terminal point of the first stage as the case for study. According to the characteristics of this project and in combination with related specifications, this paper provided the control standards for railway settlement and simulated the construction process of the down traversing formed by the double-arch tunnel on Xikang Railway via numerical simulation technique. It obtains the control standards for the railway settlement 


\section{MATEC Web of Conferences}

caused by the down traversing of the double-arch tunnel and the deformation laws of stratums and tracks; and offers the underground water treatment measures and the assistant measures for surface construction. The research conclusions can provide scientific proof and technical guidance for the design and construction of this running tunnel project in order to offer reference for similar projects in the future. See the specific conclusions as follows:

1) According to related norms and the practical experience obtained in the cases of the down traversing formed by the subways through railways in Beijing, Guangzhou and Shanghai, and in combination with the underground tunnel excavation construction experience accumulated in $\mathrm{Xi}^{\prime}$ an and the engineering geological conditions of this subway running tunnel, certain control standard values have been offered for the down traversing part of the underground excavation tunnel construction.

2) During the construction of the running tunnel, settlement deformation of different degrees occurred in the surrounding rock of the tunnel and on the railroad beds. The settlement deformation value of the tunnel arch apex was the maximum value while that of the ground surface was the minimum one. According to the prepared tunnel support parameters and related treatment measures, the railroad track structural settlement value, differential settlement value and track gauge change value caused by the down traversing of the tunnel can meet the requirements in the control standards.

3) The distance between the maximum curvature points of the settling tank caused by the excavation of the tunnel can be calculated according to PECK formula. In combination of the numerical simulation results, it can be concluded that the main range of the soil mass settlement that occurs during the down traversing of the tunnel is $-20 \sim+20 \mathrm{~m}$ of the tunnel center line along the longitudinal direction of the railway tracks. While arranging the monitoring spots of the rail track structure and reinforcing it, this area shall be paid the most attention to.

4) With the development of the excavation in the running tunnel and the supporting process, the settlement deformation of the railroad beds increased. According to the numerical simulation calculation, the settlement value of the railroad beds caused by the excavation of the middle hole accounted for $70 \%$ of the overall settlement value. The excavation of the middle hole shall be emphasized in the construction, so as to reduce the adverse effect caused by the deformation of the rail tracks.

5) According to the statistics of the precipitation construction for the underground tunnel excavation in the loess stratum of Xi'an, the ground settlement caused by the precipitation was generally around $10 \mathrm{~mm}$. In order to reduce the accessional settlement brought by the precipitation below the railway, full-sectional grouting water plugging method has been proposed for the tunnel excavation and specific design plans have been provided.

\section{REFERENCES}

[1] Ministry of Housing and Urban-Rural Development of People's Republic of China. GB50517-2013 Code for Design of Metro. Beijing: China Planning Press, 2013.

[2] China Railway. TB10003-2005 Code for Design of Railway Tunnel. Beijing: China Railway Publishing House, 2005.

[3] China Railway. TB10204-2002 J163-2002 Job Specifications of Railway Tunnel. Beijing: China Railway Publishing House, 2002

[4] Shi Z.H. 2006. Design and Construction of Underground Railroad. Xi'an: Shaanxi Science and Technology Publishing House.

[5] Ren J.X.\& Li L., et al. 2013. Deformation Control Technology for the Down Traversing in Subway Shield Method Through the Railways in Loess Area. Journal of Railway Engineering Society, (5): 57-62.

[6] Peck R.B. 1969. Deep Excavations and Tunneling in Soft Ground, Proceedings of the 7th International Conference of Soil Mechanics and Foundation Engineering. Mexico.

[7] Zhao Guofan, Li Yungui. \&Wang Hengdong.1996. Forth Moment Method for Structure Reliability Analysis Based on Maximum Entropy Theory, Proceeding of the Sixth Workshop on Concrete Model Code for Asia .Dalian.

[8] Hmad Fahimifar, Masoud Ranjbarnia. 2009. Analytical approach for the design of active grouted rockbolts in tunnel stability based on convergence-confinement method. Tunnelling and Underground Space Technolo$g y, 24(4)$

[9] Shou K J. 2000. A three-dimensional hybrid boundary element method for non-linear analysis of a weak plane near an underground excavation. Tunnelling and Underground Space Technology, 15(2).

[10] Mair R.J. 1996. Settlement effects of bored tunnels. Geotechnical Aspects of Underground Construction in Soft Ground. Balkema.

[11]Mair R.J., Taylor R.N. \& Bracegirdle A. 1993. Subsurface settlement profiles above tunnels in lays. Geotechnique, 43(2).

[12] Attewell P.B, Yeates J. \& Selby A.R. 1986. Soil Movements Induced by Tunneling and Their Effects on Pipelines and Structures. Glasgow: Blackie. 